\title{
Impact of various herbicides treatments on controlling field dodder (cuscuta campestris yuncker) parasitizing Fenugreek plants
} (Trigonella foenum-graecum L.)

\begin{abstract}
This study was conducted to evaluate the effect of various herbicides on dodder control in Fenugreek field. Glyphosate and Stomp herbicides were applied at different rates to control the parasitic weed Cuscuta campestris Yunck.on fenugreek plants Trigonella foenum-graecum $\mathrm{L}$. Results revealed that applying glyphosate post-attachment at very low rates $(80$ and $120 \mathrm{~g} /$ fed.) exhibited selective control for attached dodder with fenugreek plants. Both glyphosate rates gave excellent dodder control and significant yield increases. Also improved fenugreek plant height, number of branches/plant, number of pods/plant and number of seeds/pod Whereas, stomp (pre-emergence herbicide) was effective only at $0.5 \mathrm{~L} / \mathrm{fed}$.. Data also showed that dodder control increased by increasing the rates of glyphosate and stomp although, at higher rates $(160 \mathrm{~g} / \mathrm{fed}$. and $1.0 \mathrm{~L} / \mathrm{fed}$.$) , seed yield can$ severely reduced and phytotoxic injury to the host plant was clearly observed. The obtained results also indicate that both herbicides were markedly increased the leaf contents of total carbohydrates, reducing sugars, chlorophylls and carotenoid, anthocyanin, proline, total free amino acids, total indoles, crude proteins and total nitrogen contents in the leaves. On the contrary, all dodder control treatments decreased total phenols and non reducing sugars in leaves as compared to the control.
\end{abstract}

Keywords: chemical control, herbicides (glyphosat and stomp), fenugreek plant, chemical constitution of leaf
Volume 3 Issue 6 - 2019

\author{
Seif El-Yazal MA,' Ali IHH ${ }^{2}$ \\ 'Departmnet of Botany, Faculty of Agriculture, Fayoum Cairo \\ University, Egypt \\ ${ }^{2}$ Departmnet of Plant protection, Faculty of Agriculture, Fayoum \\ Cairo University, Egypt
}

\begin{abstract}
Correspondence: Mohamed A Seif El-Yazal, Botany Department, Faculty of Agriculture, Fayoum University, Fayoum 635I4, Egypt, Email mas04@fayum.edu.eg
\end{abstract}

Received: December 14, 2019 | Published: December 26, 2019

\section{Introduction}

Cuscuta campestris, also known as field dodder, has emerged as a widespread weed in several continents including Africa, Asia, Europe, Australia, and South America. ${ }^{1}$ All species of the genus Cuscuta receive their required mineral, water, and carbohydrates from their host plants because of the lake roots and leaves; besides some of the species of this genus are not able in terms of photosynthesis, including forage crops (especially fenugreek) and vegetables, some tree crops (grapevine, coffee), and ornamentals plants. ${ }^{2}$ The genus Cuscuta contains numerous species, all of which are known in English by the common name "dodder". All species of Cuscuta are obligate parasites that attack the stems and leaves of the host plants. Most of them parasites several species of dicotyledonous plants, among the dicotyledonous crop plants, legumes are found to be more susceptible to Cuscuta. Fenugreek (Trigonella foenum-graecum L.) is one of the most susceptible hosts to the field dodder (C. campestris Yunck.) infection. Heavy infestation of Cuscuta without control result in great yield losses and sometimes lead to a total failure of yield. ${ }^{3}$ Various approaches have been introduced including cultural, mechanical, chemical, use of resistant varieties, and biological to curb the negative effects of parasitic weeds; but most of them failed to achieve this aim. ${ }^{4}$ One of the parasitic plant is field dodder, which is found on the stems and leaves of broadleaf plants, including weeds, field crops, vegetables, and ornamentals around the world. It is not easy to control field dodder because of close intimacy and interaction between the host and the parasite; thus, there must be herbicide that attacks the parasite without inflicting damage on the host. ${ }^{5}$ The use of various herbicides for dodder control has been studied by many investigators among them, Ali and Seif El-Yazal ${ }^{3}$ on Nerium oleander L; Goldwasser et al. ${ }^{6}$ on tomato; Ziveh et al. ${ }^{7}$ on sugar beet; Zaroug et al. ${ }^{8}$ on onion; Sarić-Krsmanović et al. ${ }^{9}$ on alfalfa; Meighani et al..$^{10}$ and Hoseyni et al. ${ }^{4}$ on sugar beet.

The present work aimed to determine the proper rates of glyphosate and stomp herbicides that would control dodder without causing phytotoxicity on fenugreek seed plants, in addition to study the effect of both herbicides on some chemical constituents and seed yield of fenugreek plants.

\section{Material and methods}

Two field experiments were carried out at the Experimental Farm of the Faculty of Agriculture at Fayoum, Cairo University during two winter successive seasons, 2002and 2003 using a complete randomized block design with four replicates. The plot area was $10.5 \mathrm{~m}(3 \times 3.5 \mathrm{~m})$. Fenugreek, Giza 30 was inoculated and seed in each experiment were planted at the rate of $20 \mathrm{Kg} / \mathrm{fed}$. The different treatments used are summarized in Table 1

\section{Herbicides used}

Glyphosate $48 \%$ W.S.C. (herbazed), post-emergence).

$\mathrm{N}$-(phosphonomethyl)glycine, was applied at the rate of 40,80,120 and $160 \mathrm{~g} / \mathrm{fed}$. as post-attachment (six weeks after sowing). 
Table I The different used treatments

\begin{tabular}{ll}
\hline I & Control (without infection and without herbicides) \\
2 & Dodder infection + water \\
3 & Dodder infection + Glyphosate at $40 \mathrm{~g} / \mathrm{fed}$. \\
4 & Dodder infection + Glyphosate at $80 \mathrm{~g} / \mathrm{fed}$. \\
5 & Dodder infection + Glyphosate at $120 \mathrm{~g} / \mathrm{fed}$. \\
6 & Dodder infection + Glyphosate at $160 \mathrm{~g} / \mathrm{fed}$. \\
7 & Dodder infection + Stomp at $0.250 \mathrm{~L} / \mathrm{fed}$. \\
8 & Dodder infection + Stomp at $0.500 \mathrm{~L} / \mathrm{fed}$. \\
9 & Dodder infection + Stomp at $\mathrm{I.000 \textrm {L } / \mathrm { fed } .}$
\end{tabular}

Stomp 50\% E.C. (pendimethalin), pre-emergence).

$\mathrm{N}-(1-$ ethyl propyl)-3,4- dimethyl-2,6- dinitrobenzenamine, was applied at the rate of $0.250,0.500$ and $1.000 \mathrm{~L} / \mathrm{fed}$. as pre-emergence (after seeding and pre-irrigation).

\section{Data recorded}

\section{Dodder control}

Percent dodder control was measured by counting the seedlings that wrapped around the host and produced visible haustoria, as described by Orloff et al.

\section{Fenugreek}

Random samples of ten guarded plants in each plot were taken at160 days from planting to estimate: plant height and number of branches/plant. At harvest, (180 days from planting), number of pod / plant, number of seeds/ pod, weight of 100-seeds and seed yield per plant were recorded.

\section{Chemical analysis}

For each treatments leaf samples were collected in the morning at flowering stage (145 days from planting),each sample was analyzed twice for:-

\section{Determination of nitrogen $(\mathrm{N})$}

Total N (\%)and crude protein percentage in dried material of leaves was determined by using micro-Kjeldahl method described by the A.O.A.C. ${ }^{11}$

\section{Determination of total free amino acids}

Total free amino acids were determined according to Jayarman ${ }^{12}$ with some modifications. ${ }^{13}$ A sample of leaves was extracted with 50 $\mathrm{ml}$ of $80 \%$ ethanol and filtered to remove insoluble materials, and then $1.0 \mathrm{ml}$ of ethanol extract was added. Then, $0.5 \mathrm{ml}$ of $0.07 \mathrm{~mol}$ 1-1 phosphate buffer solutions ( $\mathrm{pH} 8.04$ ) and $0.5 \mathrm{ml}$ of $2 \%$ ninhydrin solution containing $0.8 \mathrm{mg} \mathrm{ml}^{-1}$ of $\mathrm{SnC}_{12}-2 \mathrm{H}_{2} \mathrm{O}$ was added. The mixtures were then placed on a boiling water bath for $15 \mathrm{~min}$, and then quickly cooled with cold water, and adjusted to $25 \mathrm{ml}$ with water. After leaving to stand still for $10 \mathrm{~min}$, the absorbance values of these blue-purple products were measured against a reagent blank at 550 nm.

\section{Determination of free proline}

Free proline was determined according to the method of Bates et al. ${ }^{14}$ with slight modification as described by Ennajeh et al. ${ }^{15}$ Briefly, the sample of leaves was extracted with $5 \mathrm{ml}$ of $40 \%(\mathrm{v} / \mathrm{v})$ methanol heated to $80 \mathrm{C}$ for $30 \mathrm{~min}$ in hermetically sealed tubes. The supernatant $(1 \mathrm{ml})$ was mixed in a test tube with $2 \mathrm{ml}$ glacial acetic acid, $1 \mathrm{ml}$ ninhydrin solution ( $25 \mathrm{mgml}-1)$ and $2 \mathrm{ml}$ of a mixture consisting of 24 $\%(\mathrm{v} / \mathrm{v})$ distilled water, $60 \%(\mathrm{v} / \mathrm{v})$ glacial acetic acid and $16 \%(\mathrm{v} / \mathrm{v})$ orthophosphoric acid. The tubes were closed and heated for $30 \mathrm{~min}$ in a water bath set to $100 \mathrm{C}$. The samples were cooled on ice, then 3 $\mathrm{ml}$ of toluene was added and the mixture was shaken vigorously. The colored toluene phase (upper phase) was saved and dehydrated with anhydrous $\mathrm{Na} 2 \mathrm{SO} 4$. The extracts were kept in the dark for a minimum of $2 \mathrm{~h}$ before their absorbance was measured at $528 \mathrm{~nm}$. The proline content of fresh bud was calculated based on a standard calibration curve with concentrations ranging from 0 to $0.025 \mathrm{mg} \mathrm{ml}-1$.

\section{Determination of total indoles}

Total indoles were extracted from leaves by grinding $2 \mathrm{~g}$ with 50 $\mathrm{ml}$ toluene and $5 \mathrm{ml} \mathrm{5 \%}$ TCA for $1 \mathrm{~min}$. The mush was centrifuged at $2500 \times \mathrm{g}$ for $30 \mathrm{~min}$ to separate the toluene layer that was filtered through a $0.45 \mathrm{~m}$ syringe filter into a beaker containing anhydrous $\mathrm{Na} 2 \mathrm{SO} 4$ (Aldrich). Total indoles were determined (as $\mathrm{mg} / \mathrm{g}$ fresh weight) according to Larson et al. ${ }^{16}$ The extract $(4 \mathrm{ml})$ was diluted to $10 \mathrm{ml}$ with toluene, after which $2 \mathrm{ml}$ was vortexed for $15 \mathrm{~min}$ with $2 \mathrm{ml}$ reagent (1.25 g [4-dimethyl-aminobenzaldehyde (DMAB)] in $100 \mathrm{ml} \mathrm{MeOH}$ and $25.6 \mathrm{ml}$ concentrated $\mathrm{HCl}$ ). The mixture was centrifuged at $3500 \mathrm{rpm}$ for $6 \mathrm{~min}$ to separate the $\mathrm{MeOH}$ (bottom) layer that was measured with spectrophotometer at $567 \mathrm{~nm}$. 2.9.

\section{Determination of anthocyanin}

Total anthocyanin content was determined by the method of Hoagland. ${ }^{17}$ Dried leaves were extracted with $1 \% \mathrm{HCl}-\mathrm{MeOH}$ for $24 \mathrm{~h}$ at room temperature in darkness with occasional shaking. The extract was carefully decanted and their absorbance was measured at 530 and $657 \mathrm{~nm}$. The formula A530-0.25 A657 was used to compensate the absorption of chlorophyll degradation products. Anthocyanin content was expressed as $\mathrm{mg}$ of cyaniding 3-glucoside in $100 \mathrm{~g}$ dry leaves, using 29,600 as molecular extinction coefficient.

\section{Determination of total carbohydrates}

Total carbohydrates $\mathrm{mg} / \mathrm{g}$ D.W were determined colorimetrically according to the method described by Michel et al. ${ }^{18}$ Total and reducing sugars were determined according to A. O. A. C. ${ }^{11}$ and recorded as $\mathrm{mg} / \mathrm{g}$ fresh weight. Non reducing sugars were obtained by subtracting reducing sugars from total sugars and recorded as $\mathrm{mg} / \mathrm{g}$ fresh weight.

\section{Determination of total soluble phenols}

Total soluble phenols $\mathrm{mg} / \mathrm{g}$ fresh weight were determined according to A. O. A. C. ${ }^{11}$

\section{Determination of chlorophyll}

The concentration of chlorophyll $\mathrm{a}, \mathrm{b}$ and carotenoids $\mu \mathrm{g} / \mathrm{g}$ fresh weight were determined according to Welburn and Lichtenthaler. ${ }^{19}$

The values presented in the results obtained in this investigation is the mean of the two seasons under the study.

\section{Statistical analysis:}

All data of each season were statistically analyzed according to Snedecor and Cochran..$^{20}$ Means were compared using the least significant difference (L.S.D.) test at 0.05 significance level. 


\section{Results}

\section{Growth characters}

Data in Table 2 show that dodder infection exhibited significant decrease in plant height by $31.03 \%$ and $33.04 \%$ under the control plant during the two seasons respectively. The data in Table 2 also show that all treatments of both the two herbicides improved fenugreek plant height over the infected plants and reduce the adverse effect of dodder on plant height. The best results were obtained by applying glyphosate at $(80$ and $120 \mathrm{~g} / \mathrm{fed}$.) and stomp at $(0.500 \mathrm{~L} / \mathrm{fed}$.). The increase gained by glyphosate at ( 80 and $120 \mathrm{~g} / \mathrm{fed}$.) were $20.68 \%$ and $31.03 \%$ over the control in first seasons and $26.73 \%$ and $30.43 \%$ over the control in the second season respectively. The increases gained by stomp at $(0.500 \mathrm{~L} /$ fed. $)$ were $14.94 \%$ and $15.21 \%$ over the control in the two successive seasons respectively.

The number of branches/plant was generally decreased by dodder infection the decrease were $42.85 \%$ and $29.33 \%$ under the control plants in the two seasons respectively. The number of branches/ plant was also affected by treating with the two herbicides. The best results were obtained by glyphosate at 80 and $120 \mathrm{~g} /$ fed. and stomp at $(0.500 \mathrm{~L} / \mathrm{fed}$.). The increase was $21.42 \%, 42.85 \%$ and $14.28 \%$ over the control in the first seasons respectively and $33.33 \%, 33.33 \%$ and $24.00 \%$ over the control in the second seasons respectively.

\section{Yield of seeds and its components}

Data in Table 2 generally show that dodder infection decreased the yield of seeds and its components as compared with the control plants, the decrease were $38.62 \%$ and $35.00 \%$ in number of pods/ plant, $25.73 \%$ and $28.57 \%$ in number of seeds/pod, $9.93 \%$ and $12.58 \%$ in 100 seed weight and $57.37 \%$ and $55.79 \%$ in seed yield under the control plants in both seasons respectively.

In contrast the data presented in Table 2 clearly show that, the number of pods/plant was significantly increased by treating with the two herbicides over the infected plants and reduce the adverse effect of dodder on number of pods/plant except those plants treated with the high concentration of stomp at $(1.0 \mathrm{~L} / \mathrm{fed}$.). The best results were obtained by glyphosate at (80 and $120 \mathrm{~g} / \mathrm{fed}$.) and stomp at $(0.500 \mathrm{~L} / \mathrm{fed}$.$) . The increase were 27.58 \%, 41.89 \%$ and $12.06 \%$ for glyphosate at (80 and $120 \mathrm{~g} /$ fed. $)$ and stomp at $(0.500 \mathrm{~L} / \mathrm{fed}$.$) in$ the first seasons respectively, and $30.00 \%, 39.19 \%$ and $16.61 \%$ in the second seasons as compared with the control As regard to the number of seeds/pod obtained by treating the infected plants with the different rates of both glyphosate and stomp herbicides did not give any significant effect compared with the control except those plants treated with glyphosate at 80 and $120 \mathrm{~g} / \mathrm{fed}$. and stomp at $0.500 \mathrm{~L} /$ fed. which exhibited insignificant increase in the two seasons. The increase gained by glyphosate at 80 and $120 \mathrm{~g} / \mathrm{fed}$ and stomp at 0.500 $\mathrm{L} /$ fed.) were $8.59 \%, 17.18 \%$ and $39.45 \%$ over the control in the first season and $8.57 \%, 14.28 \%$ and $00.71 \%$ over the control in the second season respectively.

Also, insignificant increase in the weight of 100 seeds were obtained by treating with the different rates of both glyphosate and stomp herbicides compared with the control except those plants treated with glyphosate at $(80$ and $120 \mathrm{~g} / \mathrm{fed}$.) which exhibited significant increase in the two seasons (Table 2). The percent of increase were $11.25 \%$ and $12.58 \%$ over the control in the first season and $10.06 \%$ and $14.46 \%$ over the control in the second season respectively.
As regard to the effect of the two herbicides on fenugreek seed yield the data in Table 2 indicate that spraying with glyphosate and stomp herbicides give significant increase in the seed yield over the infected plants and reduce the adverse effect of dodder on seed yield. On the other hand the treatments also give insignificant increase in the seed yield over the control. The best results were obtained by glyphosate at 80 and $120 \mathrm{~g} / \mathrm{fed}$. and stomp at $(0.500 \mathrm{~L} / \mathrm{fed}$.). The increase was $1.19 \%, 19.95 \%$ and $1.29 \%$ over the control in the first season respectively and by $1.71 \%, 8.90 \%$ and $00.45 \%$ over the control in the second season respectively. The lower and higher rates of both herbicides did not give any significant effect on the seed yield in the two seasons compared with the control plant.

\section{Dodder control}

Data in Table 2 indicate that spraying of glyphosate at ( $80 \mathrm{~g}$ and $120 \mathrm{~g} /$ fed.) controlled about ( $75 \%$ and $83 \%$ of dodder during the first season respectively and controlled about $82 \%$ and $85 \%$ of dodder during the second season respectively. While applying stomp (preemergence herbicide) at $0.500 \mathrm{~L} /$ fed. controlled about (68-74) percent of dodder in both seasons respectively. The higher rates of dodder control (92-94 \%) and (90-93 \%) was obtained by treating with $160 \mathrm{~g} /$ fed. glyphosate and $1.0 \mathrm{~L} /$ fed stomp respectively with phytotoxicity the fenugreek plant during the two seasons. Thus glyphosate at 80 or $120 \mathrm{~g} / \mathrm{fed}$ and stomp at $0.50 \mathrm{~L} / \mathrm{fed}$ are recommended and can be used safely to control attached dodder selectively.

\section{Dry weight of Leaves}

Data presented in Table (3) generally show that dry weight of leaves were decreased as a result of dodder infection when compared with control plants this decrease reached about $15.59 \%$. Dodder controlled plants with. glyphosate and stomp were reduced the adverse effect of dodder on dry weight of leaves except those plants treated with high concentration of the two herbicides. The best results were obtained by glyphosate at 80 and $120 \mathrm{~g} / \mathrm{fed}$. and stomp at $0.500 \mathrm{~L} / \mathrm{fed}$. The increase gained by glyphosate at 80 and $120 \mathrm{~g} / \mathrm{fed}$. and stomp at 0.500 L/fed. were $3.14 \%, 2.59 \%$ and $2.49 \%$ over the control .

\section{Chemical analysis:}

\section{Leaf pigments}

\section{Plastid pigments}

The present results in Table 3 show that chlorophyll a, b and carotenoids in leaves were decreased due to dodder infection. The decrease were $27.36 \%, 26.01 \%$ and $52.91 \%$ respectively as compared to control plants .Treating with glyphosate at (80and $120 \mathrm{~g} / \mathrm{fed})$ and stomp at $0.500 \mathrm{~L} /$ fed increased the plastid pigments insignificantly as compared to the control. The increase were $1.21 \%, 1.69 \%$ and $0.12 \%$ for chlorophyll a $, 0.22 \%, 5.65 \%$ and $0.22 \%$ for chlorophyll $\mathrm{b}$ and $0.40 \%, 4.06 \%$ and $0.20 \%$ for carotenoids respectively over the control.

\section{Cell-sap pigments}

Data in Table 3 indicates that anthocyanin concentration in plant leaves were greatly decreased in dodder infected plants. The decrease were $22,96 \%$ under the control plants. The data also show that treating with both herbicides were increased the anthocyanin significantly as compared to the infected plants and insignificantly as compared to the control .The best results were obtained by glyphosate at $(80 \mathrm{~g}$ and 120 $\mathrm{g} /$ fed) and stomp at $0.500 \mathrm{~L} / \mathrm{fed}$. The increases were $3.88 \%, 7.09 \%$ and $6.45 \%$ over the control respectively. 
Table 2 Effect of glyphosate and stomp herbicides on growth parameters and seed yield of fungreek plants

\begin{tabular}{|c|c|c|c|c|c|c|c|c|c|c|c|c|c|c|}
\hline \multirow{2}{*}{ Treatments } & \multicolumn{2}{|c|}{$\begin{array}{l}\text { Dodder } \\
\text { controle (\%) }\end{array}$} & \multicolumn{2}{|c|}{$\begin{array}{l}\text { Plant height } \\
\text { (cm) }\end{array}$} & \multicolumn{2}{|c|}{$\begin{array}{l}\text { No. of branches/ } \\
\text { plant }\end{array}$} & \multicolumn{2}{|c|}{$\begin{array}{l}\text { No. of pods/ } \\
\text { plant }\end{array}$} & \multicolumn{2}{|c|}{$\begin{array}{l}\text { No of seeds/ } \\
\text { pod }\end{array}$} & \multicolumn{2}{|c|}{$\begin{array}{l}\text { l00seed } \\
\text { weight }(\mathrm{g})\end{array}$} & \multicolumn{2}{|c|}{$\begin{array}{l}\text { Seed yield ( } g / \\
\text { plant) }\end{array}$} \\
\hline & 2002 & 2003 & 2002 & 2003 & 2002 & 2003 & 2002 & 2003 & 2002 & 2003 & 2002 & 2003 & 2002 & 2003 \\
\hline Control & 00 & 00 & 43.5 & 46.0 & 7.0 & 7.5 & 58.0 & 62.0 & 12.8 & 14.0 & 1.51 & 1.59 & 40.04 & 46.06 \\
\hline $\mathrm{D}+\mathrm{H}_{2} \mathrm{O}$ & 00 & 00 & 30.0 & 30.8 & 4.0 & 5.3 & 35.6 & 40.3 & 9.25 & 10.0 & 1.36 & 1.39 & 17.05 & 20.36 \\
\hline$D+40 G$ & 60 & 66 & 46.8 & 49.0 & 7.0 & 8.0 & 60.3 & 66.0 & 12.0 & 13.0 & 1.53 & 1.60 & 31.72 & 35.0 \\
\hline$D+80 G$ & 75 & 82 & 52.5 & 58.3 & 8.5 & 10.0 & 74.0 & 80.6 & 13.9 & 15.2 & 1.68 & 1.75 & 40.52 & 46.85 \\
\hline$D+120 G$ & 83 & 85 & 57.0 & 60.0 & 10.0 & 10.0 & 82.3 & 86.3 & 15.0 & 16.0 & 1.70 & 1.82 & 48.03 & 50.16 \\
\hline$D+160 G$ & 92 & 94 & 38.0 & 42.5 & 6.0 & 6.8 & 48.6 & 49.0 & 11.0 & 10.6 & 1.41 & 1.41 & 20.63 & 22.04 \\
\hline$D+0.250 S$ & 41 & 52 & 40.2 & 45.5 & 6.3 & 7.0 & 53.0 & 60.0 & 10.5 & 12.0 & 1.46 & 1.51 & 25.00 & 29.38 \\
\hline $\mathrm{D}+0.500 \mathrm{~S}$ & 68 & 74 & 50.0 & 53.0 & 8.0 & 9.3 & 65.0 & 72.3 & 12.9 & 14.1 & 1.59 & 1.72 & 40.56 & 46.27 \\
\hline$D+1.000 S$ & 90 & 93 & 35.0 & 32.8 & 5.0 & 4.5 & 42.6 & 39.0 & 9.6 & 11.0 & 1.40 & 1.40 & 19.42 & 18.25 \\
\hline $\begin{array}{l}\text { L.S.D. } \\
0.05 \%\end{array}$ & 10.99 & 7.84 & 6.81 & 7.30 & 1.53 & 2.69 & 8.52 & 10.34 & 3.24 & 3.50 & 0.16 & 0.15 & 8.04 & 10.37 \\
\hline
\end{tabular}

D, Dodder infection; G, Glyphoosate herbicide (g/fed.); S, Stomp herbicide L/fed.)

Table 3 Effect of glyphosate and stomp herbicides on dry weight, chlorophylls, anthocyanin, total carbohydrates of fungreek plants

\begin{tabular}{|c|c|c|c|c|c|c|}
\hline Treatments & $\begin{array}{l}\text { Dry weight } \\
(\%)\end{array}$ & $\begin{array}{l}\text { Chl A } \\
\text { (ug/g)F.W. }\end{array}$ & $\begin{array}{l}\text { Chl B (ug/g) } \\
\text { F.W. }\end{array}$ & $\begin{array}{l}\text { Carotenoids } \\
\text { (ug/g)F.W. }\end{array}$ & $\begin{array}{l}\text { Anthocyanin } \\
\text { (mg/l00g) D.W. }\end{array}$ & $\begin{array}{l}\text { Total carbohydrates } \\
\text { (mg/g) D.W. }\end{array}$ \\
\hline Control & 20.01 & 826 & 442 & 246.00 & 26.48 & 96.75 \\
\hline $\mathrm{D}^{*}+\mathrm{H}_{2} \mathrm{O}$ & 16.89 & 600 & 327 & II 5.83 & 20.40 & 81.25 \\
\hline $\mathrm{D}^{*+4}+40\left(\mathrm{G}^{* *}\right)$ & 17.59 & 662 & 390 & 185.46 & 23.00 & 83.27 \\
\hline $\mathrm{D} *+80\left(\mathrm{G}^{* *}\right)$ & 20.64 & 836 & 443 & 247.00 & 27.51 & 100.16 \\
\hline$D^{*+1} 20\left(\mathrm{G}^{* *}\right)$ & 20.53 & 840 & 467 & 256.00 & 28.36 & 102.15 \\
\hline$D^{*+1} 160\left(G^{* *}\right)$ & 15.48 & 621 & 327 & 217.00 & 21.39 & 79.08 \\
\hline $\mathrm{D}^{*+0}+250\left(\mathrm{~S}^{* * *}\right)$ & 19.76 & 795 & 338 & 117.24 & 21.50 & 94.50 \\
\hline $\mathrm{D} *+0.500\left(\mathrm{~S}^{* * *}\right)$ & 20.51 & 827 & 443 & 246.50 & 28.19 & 104.00 \\
\hline$D^{*}+1.000\left(S^{* * *}\right)$ & 18.30 & 732 & 377 & 219.98 & 24.17 & 90.83 \\
\hline L.S.D. $0.05 \%$ & 2.16 & 17.65 & 9.79 & 12.85 & 0.90 & 3.084 \\
\hline
\end{tabular}

*Dodder infection **Glyphoosate herbicide (g/fed.). ***Stomp herbicide (L/fed.)

\section{Carbohydrates}

Data in Table 3 indicates that total carbohydrates concentrations in leaves were decreased in the dodder infected plants as compared to the control plants, this decrease were $16.02 \%$ under the control plants. Treating with glyphosate and stomp herbicides increased the concentration of total carbohydrates compared with the infected plants .The highest increase were obtained by glyphosate at $80 \mathrm{~g}$ and $120 \mathrm{~g} /$ fed. and stomp at $0.500 \mathrm{~L} / \mathrm{fed}$. The increase gained by glyphosate at ( 80 and $120 \mathrm{~g} /$ fed.) and stomp at $0.500 \mathrm{~L} /$ fed. were $3.52 \%, 5.58 \%$ and $7.49 \%$ over the control respectively. On the other hand high concentration of glyphosate at $160 \mathrm{~g} / \mathrm{fed}$. decrease this concentration.

The present data in Table 4 reveal that total and reducing sugars concentrations in leaves were decreased under dodder infected plants as compared to the control plants, this decrease reached to $3.28 \%$ for total sugars and $8.09 \%$ for reducing sugars under the control plants. The two studied herbicides under investigation caused an increase in total and reducing sugars. The increase gained by glyphosate at $(80 \mathrm{~g}$ and $120 \mathrm{~g} /$ fed.) were $(4.33 \%$ and $4.22 \%)$ for total sugars, $(78.77 \%$ and $78.59 \%$ ) for reducing sugars respectively over the control. Also, the increase obtained by stomp at $0.50 \mathrm{~L} /$ fed. were $(5.50 \%)$ for total sugars and (63.66\%) for reducing sugars respectively over the control. Data in Table (4) also show that non reducing sugars concentrations in leaves were decreased under dodder infected plants as compared with the control plants, this decrease were $0.95 \%$ under the control plants. Also all dodder control treatments depressed to different extends, the amount of non- reducing sugar as compared to the control. The high depression were obtained by glyphosate at $80 \mathrm{~g}$ and $120 \mathrm{~g} / \mathrm{fed}$. 
and stomp at $0.500 \mathrm{~L} / \mathrm{fed}$. The decrease reached about $31.65 \%$ and $31.73 \%$ for glyphosate at 80 and $120 \mathrm{~g} /$ fed. and $22.60 \%$ for stomp at $0.500 \mathrm{~L} /$ fed. under the control respectively .

\section{Total free amino acids and free proline}

Data in Table 4 indicates that total free amino acids and free prolin in leaves were decreased under dodder infected plants if compared with the control plant, the decrease were $16.73 \%$ for total free amino acids and $29.45 \%$ for proline respectively. Also, total free amino acids and free proline in leaves were insignificantly increased at high concentrations $(160 \mathrm{~g} / \mathrm{fed}$. and $1.000 \mathrm{~L} / \mathrm{fed}$.) of glyphosate and stomp herbicides if compared with the control plants. The highest increase were obtained by glyphosate at $80 \mathrm{~g}$ and $120 \mathrm{~g} / \mathrm{fed}$. and stomp at 0.500 $\mathrm{L} /$ fed. The increase gained about $14.79 \%, 14.05 \%$ and $12.02 \%$ in total free amino acids, $14.44 \%, 17.09 \%$ and $9.76 \%$ in free proline by glyphosate at 80 and $120 \mathrm{~g} /$ fed. and stomp at $0.500 \mathrm{~L} /$ fed. Respectively over the control.

\section{Nitrogen concentration and crude protein}

Data in Table 5 show that nitrogen and crude protein concentrations in leaves were significantly decreased due to dodder infected plants, the decrease were $28.21 \%$ for nitrogen and crude protein as compared with the control plants. Glyphosate and stomp herbicides resulted in an increase in these compounds reached about $15.92 \%$ and $26.53 \%$ for glyphosate at 80 and $120 \mathrm{~g} /$ fed and $23.74 \%$ for stomp at $0.500 \mathrm{~L} /$ fed. in nitrogen and crude protein concentrations respectively over the control.

Table 4 Effect of glyphosate and stomp herbicides on, total sugars, reducing sugars, non reducing sugars, total free amino acids and free proline of fungreek plants

\begin{tabular}{|c|c|c|c|c|c|}
\hline Treatments & $\begin{array}{l}\text { Total sugars } \\
\text { (mg/g)F.W. }\end{array}$ & $\begin{array}{l}\text { Reducing sugars } \\
\text { (mg/g)F.W. }\end{array}$ & $\begin{array}{l}\text { Non reducing } \\
\text { sugars }(\mathrm{mg} / \mathrm{g}) \mathrm{F} . W .\end{array}$ & $\begin{array}{l}\text { Total free amino } \\
\text { acids } \\
(\mathrm{mg} / \mathrm{g}) \text { D.W. }\end{array}$ & $\begin{array}{l}\text { Free proline } \\
\text { (mg/g)D.W. }\end{array}$ \\
\hline Control & 17.06 & 5.56 & 11.50 & 23.12 & 14.44 \\
\hline D*+ $\mathrm{H}_{2} \mathrm{O}$ & 16.50 & 5.11 & 11.39 & 19.25 & 10.11 \\
\hline$D^{*+40}\left(G^{* *}\right)$ & 17.42 & 7.81 & 9.61 & 20.80 & 11.15 \\
\hline$D^{*+80}\left(G^{* *}\right)$ & 17.80 & 9.94 & 7.86 & 26.54 & 16.40 \\
\hline$D^{*}+120\left(G^{* *}\right)$ & 17.78 & 9.93 & 7.85 & 26.37 & 16.78 \\
\hline$D *+160(G * *)$ & 17.50 & 8.53 & 8.97 & 25.80 & 15.60 \\
\hline$D^{*}+0.250\left(S^{* * *}\right)$ & 17.75 & 8.25 & 9.43 & 19.76 & 10.24 \\
\hline$D^{*+0}+.500\left(S^{* * *}\right)$ & 18.00 & 9.10 & 8.90 & 25.90 & 15.73 \\
\hline$D^{*+1} .000\left(S^{* * *}\right)$ & 17.50 & 6.17 & 11.33 & 25.73 & 15.06 \\
\hline L.S.D. $0.05 \%$ & 1.69 & 1.74 & 1.24 & 2.63 & 1.19 \\
\hline
\end{tabular}

*Dodder infection **Glyphoosate herbicide (g/fed.). ***Stomp herbicide (L/fed.)

Table 5 Effect of glyphosate and stomp herbicides on nitrogen content, crude protein, total indoles and total phenols of fungreek plants

\begin{tabular}{|c|c|c|c|c|}
\hline Treatments & Nitrogen content (\%) & Crude protein (\%) & $\begin{array}{l}\text { Total indoles } \\
(\mathrm{mg} / \mathrm{g}) \text { D.W. }\end{array}$ & $\begin{array}{l}\text { Total phenols } \\
\text { (mg/g)D.W. }\end{array}$ \\
\hline Control & 3.58 & 22.37 & 1.07 & 6.90 \\
\hline $\mathrm{D} *+\mathrm{H}_{2} \mathrm{O}$ & 2.57 & 16.06 & 1.04 & 6.06 \\
\hline$D^{*+40}\left(G^{* *}\right)$ & 3.39 & 21.18 & 1.06 & 6.13 \\
\hline$D^{*+80}\left(G^{* *}\right)$ & 4.15 & 25.93 & 1.47 & 4.85 \\
\hline$D *+120(G * *)$ & 4.53 & 28.31 & 1.54 & 4.46 \\
\hline$D *+160(G * *)$ & 2.67 & 16.68 & 1.03 & 7.29 \\
\hline$D^{*+0} 0.250\left(S^{* * *}\right)$ & 3.16 & 19.75 & 1.07 & 5.63 \\
\hline$D^{*+0} 0.500\left(S^{* * *}\right)$ & 4.43 & 27.68 & 1.36 & 5.42 \\
\hline$D^{*+1} .000\left(S^{* * *}\right)$ & 2.83 & 17.08 & 1.05 & 6.99 \\
\hline L.S.D.0.05\% & 0.52 & 3.25 & 015 & 1.24 \\
\hline
\end{tabular}

*Dodder infection **Glyphoosate herbicide (g/fed.).***Stomp herbicide (L/fed.) 


\section{Total indoles}

Data in Table 5 reveal that total indoles in leaves were significantly decreased under dodder infected plants, the decrease reached about $2.80 \%$ under the control plants. Treating with Glyphosate at 80 and 120 $\mathrm{g} /$ fed.and stomp at $0.500 \mathrm{~L} /$ fed. Increased the total indoles in leaves. This increase were $37.38 \%, 43.92 \%$ and $27.10 \%$ respectively over the control. It is also clear from Table 4 that total indoles concentration was significantly decreased by treating with the two herbicides used at high concentrations.

\section{Total Phenols}

Data in Table (5) clearly show that total phenols in leaves were significantly decreased due to dodder infection, the decrease gained about $12.17 \%$ under the control plants. Data in Table 4 also showed clearly that herbicide treatment decreased the total phenols when applied at low concentration. The percent of decrease obtained by glyphosate at $(80 \mathrm{~g}$ and $120 \mathrm{~g} / \mathrm{fed})$ and stomp at $0.500 \mathrm{~L} / \mathrm{fed}$. reached to $29.71 \%, 35.36 \%$ and $21.44 \%$ under the control respectively .On the other hand total phenols of fenugreek leaves generally increased at high concentrations $(160 \mathrm{~g} / \mathrm{fed}$ and $1.00 \mathrm{~L} / \mathrm{fed}$.) of both the two herbicides.

\section{Discussions}

It is clear from the present data that infection of plants with dodder reduce the different metabolic processes which are responsible for normal plant growth. The adverse effect on the syntheses of chlorophyll a, b, carotenoids, anthocyanin, sugars, total free amino acids, proline, $\mathrm{N}$, crude protein and plant auxin concentration which occurred as a result of dodder infection was reduced by treating the plants with the two herbicides used in this investigation. In this connection, El-Saht et al..$^{21}$ found that chlorophyll a, b and carotenoids concentration of both castor bean and maize plants treated with low concentrations of metribuzin herbicide were unaffected whereas at high concentration of herbicide significantly decreased the chlorophyll pigment concentration. Also El-Yazal and Abd ElSamie $^{22}$ reported that the increase in anthocyanin may be attributed to the increase in the concentration of sugars in plants. Also El- Saht ${ }^{23}$ reported that anthocyanin is utilized as a precursor with cytoprotective function in the secondary metabolism, this would led to a defense mechanisms in castor bean and maize seedling and plants treated with low concentration of metribuzin herbicides. Thus, the increased level of anthocyanin indicates an index for a good mechanism of plant resistance towards the changes in the environmental conditions. The reduction of total carbohydrates concentration in leaves of plant under treatment with glyphosate herbicides at high concentration $160 \mathrm{~g} / \mathrm{fed}$ . might be due to the inhibiting effect on Hill reaction. ${ }^{24}$ The increase in total and reducing sugars concentration in the present study agreed with those obtained by Hasaneen et al..$^{25}$ they observed that contents of natural products with cytoprotective functions (reducing sugars and sucrose) as well as activities of $\propto$ and B-amylase of castor bean plants supplemented with herbicide were increased significantly whereas at high concentrations of these herbicide an opposite response was apparent. Moreover the increase in total free amino acids and free prolin may be due to the interruption of protein synthesis and proteolysis which occurs in plants under herbicide treatment stress. Some results were also obtained by El- Saht and El- Maghraby ${ }^{24}$ they concluded that most herbicides are known to induce changes in the levels of natural products with cytoprotective function. The present results are in general agreement with those obtained by El- Saht. ${ }^{23}$
It is clear that at low concentration of the two used herbicides, the reduction in the concentration of total indoles was reduced while at high concentration it increased as compared to the control plants.

This reduction in IAA at high concentrations of both herbicides may be attributed to increasing activity of IAA oxidase under herbicide stress conditions. The increase in levels of IAA oxidase may have some influence on the amounts of the transported IAA, which could influence the final levels that occur in a tissue at any one time. Such increasing effect of total phenols may be attributed to that phenolic compounds constitute a part of cellular solvents and provide a reducing environment that could be adaptive mechanism for scavenging oxygen free radicals during stress, El- Shewy et al. ${ }^{26}$

The positive effect of the two herbicides on growth characters of fenugreek infected plants may be due to the role of herbicides on control dodder selectively after the parasite is attached to the host plant Dawson ${ }^{27}$ which improve early plant growth and caused improvement in the rate of essential nutrients absorption, e.g.(N.P.K.).Also to the increase in plant growth hormones such as indole acetic acids .In this respect, Dawson ${ }^{27}$ and El- Saht et al. ${ }^{21}$ generally reported that herbicides effect on plant growth was found to be associated with marked changes in the metabolism of the treated plants .Also they added that lethal quantities of glyphosate reach the dodder by translocation from the host to the parasite. In this concern, Sarić-Krsmanović et al. ${ }^{28}$ conducted a study to investigate to see how glyphosate, propyzamide, imazethapyr, and diquat herbicides are able to curb field dodder in alfalfa of Pot and field trials. The highest effectiveness of $95 \%$ and $97.5 \%$, was reported by two glyphosate application rates ( 288 and $360 \mathrm{~g}$ a.i. ha) respectively. Also, chemical control plays an important role in weed control in sugar beet production, until become established; they are very susceptible to competition from weeds. That is one reason why many growers like to use pre plant or pre-emergence herbicides. Early poste-mergence herbicide applications also help reduce competition from weeds while the sugar beets are small. ${ }^{29}$ Several studies have been conducted to evaluate the effects of herbicides on weeds. Longden ${ }^{30}$ reported that Weed did not affect the concentration of sugar (sucrose), potassium, sodium, $\alpha$ amino nitrogen, or invert sugar in the crop beets. Root and sugar yields were progressively reduced by increasing densities of weed beet. These results are generally in full agreement with those obtained by us and many investigators, El- Yazal and Abd ElSamie $^{22}$ on Faba bean; Ali and Seif El-Yazal ${ }^{3}$ on Nerium oleander L; Goldwasser et al. ${ }^{6}$ on tomato; Ziveh et al. ${ }^{7}$ on sugar beet; Zaroug et al. ${ }^{8}$ on onion; Sarić-Krsmanović et al. ${ }^{28}$ on alfalfa; Meighani et al. ${ }^{10}$ and Hoseyni et al. ${ }^{4}$ on sugar beet.

\section{Acknowledgments}

None.

\section{Conflicts of interests}

Authors declare no conflict of interest exists.

\section{References}

1. Parker C, Riches CR. Parasitic weeds of the world: biology and control - CAB Int., Wallingford, UK; 1993:333-339.

2. Albert M, Belastegui-Macadam X, Bleischwitz M, et al. Cuscuta spp: parasitic plants in the spotlight of plant physiology, economy and ecology. In: Luttge U, Beyschlag W, editors. Progress in botany. Springer, Heidelberg. 2008:267-277. 
3. Ali IHH, Seif El-Yazal MA. Efficacy of glyphosate herbicide against dodder and its impact on some biochemical parameters on host plant Nerium oleander L. and a survey of host range of some ornamentals at Fayoum. Bull Fac Agric Cairo Univ. 2011;62:494-502.

4. Hoseyni SM, Najafi H, Sani B, et al. Role of new herbicides in dodder (Cuscuta campestris) control in sugar beet (Beta vulgaris) fields. Applied Ecology and Environmental Research. 2018;16(4):5117-5125.

5. Sarić-Krsmanović M, Vrbničanin S. Field dodder life cycle and interaction with host plants- Pesticidi i Fitomedicina. 2017;32(2):95103.

6. Goldwasser V, Sazo MR, Lanini T. Control of field dodder (Cuscuta Campestris) parasitizing tomato with ALS-inhibiting herbicides. Weed Technology. 2012;26(4):740-746.

7. Ziveh PS, Fadakar F, Mahdavi V. Chemical control of dodder (Cuscuta spp.) in the sugar beet fields. Technical Journal of Engineering and Applied Sciences. 2013;3(24):3502-3505.

8. Zaroug MS, Zahran EAB, Abbasher AA, et al. Post-attachment herbicide treatment for controlling field dodder (Cuscuta Campestris Yuncker) parasitizing onion In Gezira State, Sudan. International Journal of Scientific \& Technology Research. 2014;3(5):123-127.

9. Sarić-Krsmanović M, Božić D, Malidža G, et al. Chemical control of field dodder in alfalfa. Pesticidi i Fitomedicina. 2015; 30(2):107-114.

10. Meighani F, Nezamabadi N, Karaminejad M, et al. Investigating efficacy of new herbichdes to control dodder (Cuscuta campestris) in sugarbeet (Beta vulgaris) fields. Journal of Weed Science. 2017;12:199-209.

11. AOAC. Official methods of analysis, published by the AOAC Washington DC, USA; 1995.

12. Jayarman J. Laboratory manual in biochemistry. Wiley Eastern Limited, New York. 1981;61-73.

13. Chen L, Chen Q, Zhang Z, et al. A novel colorimetric determination of free amino acids content in tea infusions with 2,4-dinitrofluorobenzene. Journal of Food Composition and Analysis. 2009;22:137-141.

14. Bates LS, RP Waldren, ID Teare. Rapid determination of free proline for water stress studies. plant and soil. 1973;39:205-207.

15. Ennajeh M, Vadel AM, Khemira H, et al. Defense mechanisms against water deficit in two olive (Olea europaea L.) cultivars 'Meski' and 'Chemlali'. J Hort Sci Biotech. 2006;81:99-104.

16. Larson P, Herlo A, Klunsour S, et al. On the biogensis of some indoles compounds in Acetobacter xylimum. Physiol Plant. 1962;15:552-565.

17. Hoagland RE. Effect of glycophosphate on metabolism of phenolic compounds. VI. Effect of glyphosime and glyphosate metabolites on phenylalanine ammonia lyase activity, growth, protein and chlorophyll an anthocyanin levels in soybean seedlings. Weed Sci. 1980;28:393.
18. Michel KA, Gilles JK, Hamiltion PA, et al. Colorimetric method for determination of sugars and related substances. Analytical chemistry. 1956;28(3):154-158.

19. Welburn AR, Lichtenthaler H. Formula and program to determine total carotenoids and chlorophyll a and bof leaf extracts in different solvents. In: Sybesma C. editor. Advances in photosynthesis Research. 1984;2:9-19.

20. Snedecor GW, Cohran WG. Statistical Methods. $7^{\text {th }}$ ed. Iowa state Univ press, Ames, Iowa, USA. 1980.

21. El-Saht HM, Hassaneen MNA, Bassyoni FM. Effects of metribuzin herbicide on nitrogen, pigments, protease and nitrate resductase activity of normal and in $\mathrm{NaCl}$ stressed castor bean and maize plants. Biol Plant. 1994;36:267.

22. El-Yazal MA, Abd El-Samie FS. Phyiological studies on the effect of weed control treatments on growth,yield and some chemical constituents of broad bean (Vicia faba L.) plants. Annals of Agric Sci Moshtohor. 2002;40:199-221.

23. El-Saht HM. Metribuzin herbicide induced a defense mechanism in normal and $\mathrm{NaCl}$ - stressed castor bean and maize plants. Egypt J Hort. 2001;28( 2):277-290.

24. El-Saht HM, El-Maghraby YH. Comparative effects of selected herbicides on nitrogen, pigmens, photosynthetic activity and nitrate reductase activity of fresh bean plants. Proc Egypt Bot Conf. 1998;1:209.

25. Hasaneen MNA, El Saht HM, Bossyoni FM. Growth, carbohydrates and associated invertase and amylase activities in castor bean and maize as affected by metribuzin and NaCl. Biol Plant. 1994:36:451.

26. El-Shewy AA, Matter FMA, El-Yazal MA. Variable response of timber tree seedlings to water logging condition. Annals of Agric Sci Moshtohor. 2001;39(1):79-93.

27. Dawson JH. Dodder (Cuscuta spp.)control in newly seeded alfalfa (Medicago sativa) with glyphosate. Weed Technol. 1990;4:880-885.

28. Sarić-Krsmanović M, Božić D, Malidža G, et al. Chemical control of field dodder in alfalfa. Pesticidi i Fitomedicina. 2015; 30(2):107-114.

29. Morishita DW. Herbicides for weed control in sugar beets-extension services of university of Idaho, Oregon state university and Washington state university. 2003;1-11.

30. Longden PC. Effects of increasing weed-beet density on sugar-beet yield and quality. Annals of Applied Biology. 1989;114(3): 527-532. 